\title{
日本人大学生の英語リスニング成績上位群と下位群の 英文読解時の眼球運動の比較
}

\author{
小山 義徳 \\ (東京大学大学院教育学研究科・博士課程) \\ Key words: 眼球運動、リスニング、リーディング
}

\section{目 的}

英語リスニング成績が高い学習者と低い学習者の英文の読 み方には、どのような違いがあるのか検討を行った。

小山（2006）はリスニング成績が高い学習者は、入力され る情報を英語の語順で継時的に処理するスキルがあるために、 一瞬で消えてしまう音声に含まれるメッセージを理解できる 可能性を指摘している。そのため、リスニング成績が高い学 習者は英文を英語の語順で読む、読み戻りが少ない読み方を していることが予想される。一方、リスニング成績が低い学 習者の理解が阻害されている原因の一つとして、情報を英語 の語順で継時的に処理するスキルが低いことが考えられる。 そのため、リスニング成績が低い学習者はリスニング成績が 高い学習者よりも、読み戻りの多い読み方をしているのでは ないだろうか。これらの仮説を検討するために、本研究では 英語リスニング上位群と下位群の眼球運動を計測し、英文読 解時の読み戻りの回数を比較を行った。

\section{方 法}

実験協力者 大学生 7 名。学習背景を尋袾たところ、全員が 英語教育を日本の中学と高校で受けてきており、英語を使用 する国で生活した経験のある者は含まれていなかった。

装置 眼球運動は竹井機器 Talk Eye を用いた。眼球運動は左 目を対象に、 $1 \mathrm{msec}$ ごとに記録された。課題となった英文は 被験者の眼から $43 \mathrm{~cm}$ 離れたコンピューターディスプレイに 提示された。

課題 実験協力者の英語リスニング能力を測定する課題と、 英文読解時の眼球運動を測定する課題の 2 つの課題を行った。

(1)英語リスニングテスト

リスニングテストは全部で 23 問。英語で流れる本文と質問 文を聞き、その後で提示される 4 択の選択肢の中から質問の 答えとして正しいものを選ぶ形式。正答の場合を 1 点とし、 23 点満点であった。

\section{(2)英文読解時の眼球運動を測定する課題}

課題は英検準 2 級相当の英文 5 問（平均 22.4 語）で、 1 行 は 81 文字で視角は約 40 度であった。キャリブレーションを 行った後、英文が提示されると同時に眼球運動の測定を行っ た。英文に未知語が含まれることで眼球運動に影響が出るこ とを避けるため、知らない単語が課題文に含まれていなかっ たか、実験後、実験協力者に尋ねチェックを行った。その結 果、未知語の含まれる課題文はなかった。

教示

(1)英語リスニングテスト

「スペースを押すと本文と質問文が流れます。質問文を聞き 終わった後で、もう一度スペースを押すと選択肢が画面に表 れますので、質問の答えとして正しいものを 1 つ選んで下さ い。と教示した。

\section{(2)英文読解時の眼球運動を測定する課題}

実験協力者に「これから 5 つの英文が提示されますので、普
段自分が英文を読むときと同じように読んで下さい」と指示 した。

読み戻りの定義 $10 \mathrm{msec}$ の間に, 左に視角 1 度以上（約 2 文 字に相当）左に読み戻った場合を読み戻りと定義し、分析を 行った。

\section{結 果}

リスニングテスト（23 点満点）の中央值（14.5 点）で実験協 力者をリスニング上位群（3名:平均点 18 点）と下位群（4 名:平均点 11.3 点) の 2 つの群に分類した

\section{読み戻りの平均数(標準偏差)}

リスニング上位群 $(\mathrm{N}=3)=84.3(51.6)$
リスニング下位群 $(\mathrm{N}=4)=148.9(87.3)$

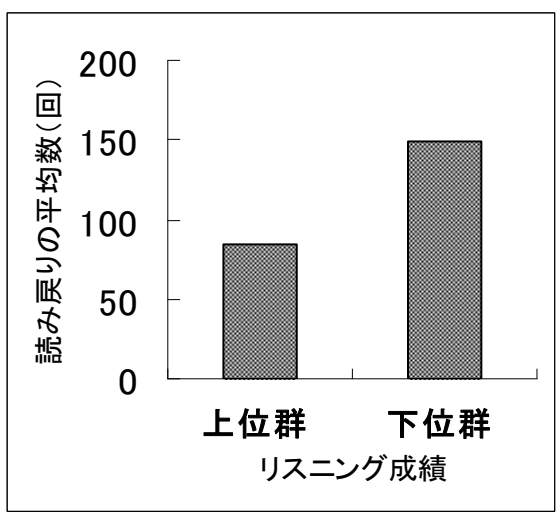

図 1 . 英語リスニング成績別・読み戻りの平均数

$\mathrm{t}$ 検定を行ったところ、リスニング上位群と下位群の英文読 解時の読み戻りの数の差は統計的に有意であった。 $(t(26)=$ $4.35, \mathrm{p}<.05)$

考 察

リスニング上位群は、下位群よりも読み戻りをすることが少 ないことが眼球運動のデータを分析した結果明らかになった。 このことから、リスニング上位群は下位群よりも視覚情報を 英語の語順で継時的に処理していることが示された。どのよ うな箇所で読み戻りが起きるかについては、提示する英文の 統語構造も含めて今後、検討する必要がある。また、英文の 読み戻りには学習者の文法力や語彙力の影響も考えられる。 そのため、これらの要因を含めた上でより統制した条件の下 で検討を行う予定である。

\section{引用文献}

小山義徳(2006)＼cjkstart英語リスニング熟達度の違いによる英文テ キスト即時処理パフォーマンスの比較. JACET第45 回 全 国大会セミナー発表. 